\title{
Membangun Ekonomi Kreatif Warga Desa Lencoh Melalui Produksi Sistik Berbasis Ta'awun
}

\author{
Muh. Naim Madjidi \\ 1. Program Studi Bahasa Arab, Fakultas Pendidikan Bahasa, Universitas Muhammadiyah Yogyakarta, Jl. Brawijaya, Geblagan, Tamantirto, \\ Kec. Kasihan, Yogyakarta, Daerah Istimewa Yogyakarta 55183, Hp: 082119940033 \\ naimmadjid@umy.ac.id \\ DOI: 10.18196/ppm.31.132
}

\begin{abstract}
Abstrak
Tulisan ini berbicara tentang pemberdayaan ibu-ibu pedukuhan Wates, desa Lencoh, kecamatan Selo, kabupaten Boyolali ke arah pembangunan ekonomi kreatif desa melalui pengolahan wortel yang merupakan salah satu hasil pertanian desa yang melimpah menjadi makanan ringan berbasis ta'awun atau gotong-royong. Kegiatan pemberdayaan ini dilakukan secara intensif melalui program pengabdian Kuliah Kerja Nyata Pembelajaran dan Pemberdayaan Masyarakat (KKN-PPM) pada tanggal 7 Januari 2020 hingga 6 Februari 2020. Terdapat 30 peserta dari kalangan ibu-ibu pedukuhan Wates yang telah mengikuti pelatihan pengolahan wortel tersebut yang diawali dengan sosialisasi tentang tujuan dan manfaat pengolahan wortel menjadi makanan ringan dalam meningkatkan ekonomi warga yang kemudian disertakan demonstrasi tata cara pengolahan, dan pada tahapan selanjutnya mereka diberi pelatihan dan pendampingan produksi sistik hingga ke tata cara pengemasan (packaging) dan pemasarannya. Prinsip ta'awun menjadi asas spirit dan keberhasilan kegiatan ini karena nilai gotong-royong dan kebersamaan yang dianutnya membuka akses bagi warga dalam meningkatkan pendapatannya sehingga manfaat benar-benar dapat dirasakan oleh ibu-ibu pedukuhan Wates melalui produksi sistik secara berkelanjutan. Hasilnya, ibu-ibu pedukuhan Wates mampu menerapkan dengan baik tahapantahapan pelatihan yang diberikan dan sebuah produk makanan ringan yang diberi nama 'Wortik' (Wortel Sisitik) berhasil dibuat oleh ibu-ibu pedukuhan dan dapat dipasarkan dengan harga yang sangat terjangkau.
\end{abstract}

Kata Kunci: Ekonomi Kreatif, Pengolahan, Sistik,Ta'awun.

\section{Pendahuluan}

Desa Lencoh adalah salah satu desa di kecamatan Selo, kabupaten Boyolali yang berlokasi di sebelah selatan gunung Merbabu dan di sebelah utara gunung Merapi. Desa ini terletak pada ketinggian 1.600 mdpl dan secara geografis berbatasan dengan desa Jeruk dan Jrakah di sebelah utara, desa Samiran dan Selo di sebelah timur, desa Klakah dan Suroteleng di sebelah selatan, dan dengan desa Jrakah di sebelah barat. Desa Lencoh terdiri dari 10 pedukuhan, $3 \mathrm{RW}$ dan $20 \mathrm{RT}$. Wates adalah salah satu pedukuhannya yang memiliki 53 kepala keluarga dengan luas wilayah $3.855 \mathrm{~m} 2$. Mayoritas penduduknya berprofesi sebagai petani. Komoditas pertanian yang ditanam yaitu hortikultura diantaranya wortel, adas, kol, dan kentang. Hasil pertaniannya langsung dijual dan kadang dikonsumsi sendiri.

Secara umum, desa Lencoh memiliki wilayah administratif yang berada di kawasan bukit yang memiliki potensi alam yang indah yang sangat akrab dengan kegiatan warga setempat. Suparlan (1980) mengatakan bahwa hubungan antara manusia dengan lingkungannya adalah hubungan timbal balik yang tak dapat dipisahkan. Demikian juga Forde (dalam Suparlan,1980) mengemukakan bahwa hubungan antara kegiatan manusia dengan lingkungan alamnya dijembatani oleh pola-pola kebudayaan yang dipunyai manusia. Dengan menggunakan kebudayaannya tersebut, maka manusia berusaha beradaptasi dengan lingkungannya. Dalam proses adaptasi tersebut, manusia mendayagunakan lingkungannya untuk tetap dapat melangsungkan kehidupannya. Pada dasarnya hubungan antara manusiadengan lingkungannya bersifat integral. Menurut Purwanto (2019) warga desa Lencoh secara umum dan warga pedukuhan Wates secara khusus masih memiliki kedekatan dengan produk-produk budayanya di mana ciri budaya masyarakat pegunungan ditandai dengan keterikatannya dengan alam sekitarnya. Hal itu dapat dilihat melalui ungkapan estetis lukisan anak-anak sekolah di desa tersebut. 


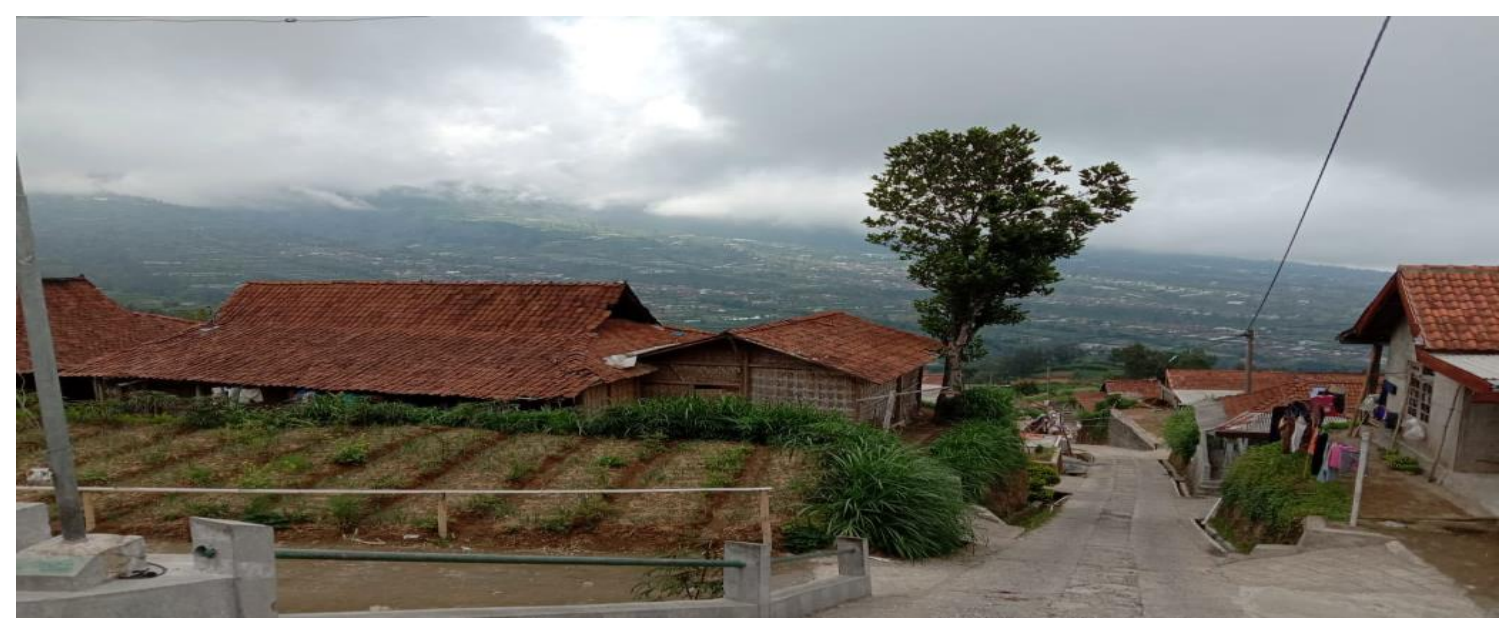

Gambar 1. View Desa Lencoh

Desa Lencoh memiliki visi 'Mewujudkan Desa Lencoh, yang Berpendidikan, Tertib, Aman, Sejahtea, Berbudaya dan Bermanfat menuju Masyarakat yang Mandiri'. Aspek kemandirian ini terlihat belum dioptimalkan sebagaimana obeservasi yang telah dilakukan oleh tim pengabdian ini yang mendapati potensi desa berupa hasil pertanian atau perkebunan yang melimpah seperti wortel, akan tetapi belum ada upaya yang optimal dan berkelanjutan untuk mengolahnya. Oleh karena itu, penulis sebagai ketua tim pengabdian mengusulkan untuk melakukan upaya pemberdayaan warga yaitu ibu-ibu pedukuhan Wates untuk mengolah waortel menjadi makanan ringan berupa sistik guna membangun ekonomi kreatif yang berbasis ta'awun (gotong-royong) yang bertujuan secara khusus untuk meningkatkan pendapatan warga desa dan mewujudkan masyarakat desa Lencoh yang mandiri.

\section{Metode Pelaksanaan}

Kegiatan pengabdian ini dilaksanakan selama 30 hari sejak tanggal 7 Januari 2020 hingga 6 Februari 2020. Pelaksanaan kegiatan ini dilakukan dalam empat tahapan utama, yaitu persiapan, pelaksanaan, monitoring dan evaluasi, dan pelaporan. Tahap persiapan meliputi pengamatan (observasi sebanyak 2 kali) untuk mengidentifikasi masalah dan pemecahannya serta melihat potensi yang ada, sosialisasi kegiatan yang telah direncanakan, pembentukan kepanitian, penjadwalan dan membuat instrumen. Tahap pelaksanaan mencakup penyampaian materi dan pendampingan pengolahan wortel menjadi sistik, pemberian motivasi dan spirit ta'awun, analisis data, serta dokumentasi. Adapun tahap monev dilakukan sebanyak 2 kali dan evaluasi terhadap kegiatan serta membuat draft laporan. Pada tahap akhir (pelaporan \& RTL) check-list dokumen pendukung dilakukan dan mulai menyusun laporan, refleksi kegiatan terhadap para peserta, umpan balik dan menyusun rencana tindak lanjut.

Metode pemilihan sampel dilakukan dengan menggunakan persampelan probabilitas dengan teknik persampelan rawak mudah (Simple Random Sampling) yang dianggap dapat menghindari terjadinya bias pemilihan sampel karena dapat mewakili populasi yang ada (Long, 2008). Maka diperoleh 30 peserta dari ibu-ibu pedukuhan Wates yang mengikut pelatihan dan pendampingan pengolahan wortel. Adapun bahan dan media yang digunakan antara lain: alat pasta maker (5 buah), wortel, tepung dan bahan lainnya, kompor, alat menggoreng, dan media presentasi menggunakan laptop dan proyektor. Secara garis besar kegiatan pelaksanaan pengabdian ini dapat digambarkan dalam alur berikut: 

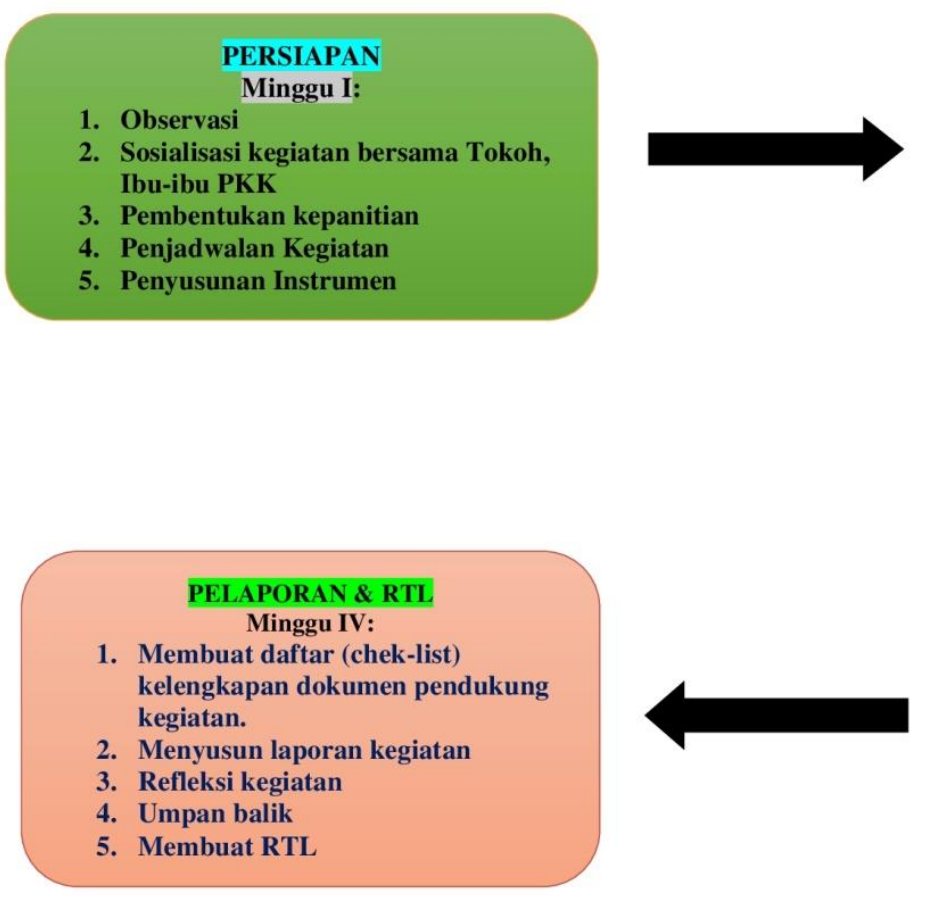

Gambar 2. Alur Pelaksanaan Pengabdian

Dalam pelatihan yang dilakukan, terlebih dahulu disampaikan kepada para peserta (ibu-ibu) tentang konsep dasar tatacara mengolah wortel menjadi makanan ringan sistik. Kemudian ditunjukkan bahan-bahan yang digunakan dan cara mengolahnya dalam bentuk demonstrasi. Selanjutnya mereka dibagi ke dalam 5 kelompok (6 orang per kelompok) dan didampingi 1 orang mahasiswa KKN untuk setiap kelompoknya. Pendampingan dilakukan sebanyak 3 kali dan berikutnya mereka diajarkan cara pengemasan (packaging) serta pemasarannya melalui dunia maya (dengan membuatkan website).

Adapun proses pengumpulan data dilakukan dengan cara dokumentasi berupa foto-foto kegiatan dan mencatat hasil pendampingan yang diberikan. Berdasarkan data yang telah diperoleh maka analisis dilakukan dengan metode analisis deskriptif yaitu dengan mendeskripsikan kegiatan pengabdian ini berupa pelatihan atau pendampingan pengolahan wortel menjadi makanan ringan sistik yang didukung dengan rujukan konsep atau teori dasar sehingga diperoleh hasil yang jelas dan dapat dipercaya.

\section{Hasil dan Pembahasan}

Konsep ta'awun atau saling tolong menolong menjadi spirit dan landasan motivasi dalam kegiatan pengabdian ini, karena ta'awun sebagaimana termaktub dalam Al-Quran surah AlMaidah ayat 2 yang artinya "dan tolong-menolonglah kalian dalam (mengerjakan) kebaikan dan takwa dan jangan tolong-menolong dalam berbuat dosa dan permusushan". Para mufasir berbeda pendapat dalam menafsirkan ayat-ayat yang berkenaan dengan ta'awun dalam AlQur'an. Menurut Hamka misalnya, ta 'awun adalah sikap tolong menolong dan bantu membantu. Dalam tafsirnya beliau menjelaskan "diperintahkan hidup bertolong-tolongan, dalam membina Al-Birru, yaitu segala ragam dan maksud yang baik dan berfaedah, yang didasarkan pada menegakkan takwa; yaitu mempererat hubungan dengan Tuhan. "Dan janganlah bertolongtolongan atas berbuat dosa dan menimbulkan permusuhan dan menyakiti sesama manusia. Tegasnya merugikan orang lain”. Sedang Qardhawi meyebut ta'awun itu sama dengan takaful, yaitu kesetiakawanan. Islam mengajarkan kepada kita agar hidup dalam masyarakat dengan senantiasa menjalin hubungan kesetiakawanan dan kerjasama sepanjang hal tersebut berkaitan dengan perkara-perkara sosial, muamalah dan kemasyarakatan. Sehinga ta'awun ini bisa 
dilakukan dengan apa saja dan dengan siapa saja tanpa adanya aturan persyaratan. Semua bisa mengerjakannya, baik yang masih kecil, remaja dan dewasa, tua atau muda, sepanjang dalam hal mengerjakan kebaikan dan kebajikan (Mubarok, 2019).

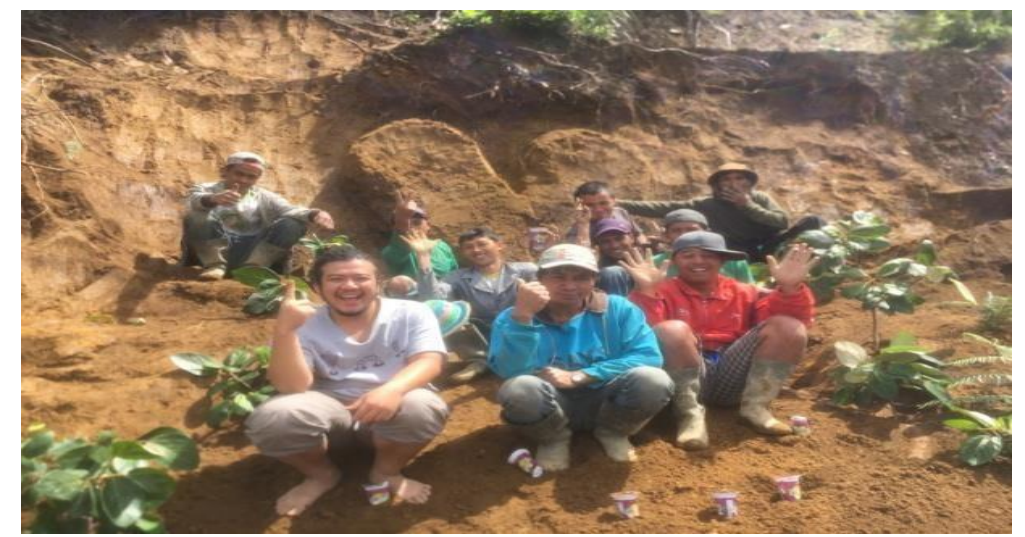

Gambar 3. Pelaksanaan penanaman tanah dataran tinggi Lencoh

Melalui program Kuliah kerja Nyata Pembelajaran dan Pemberdayaan Masyarakat (KKNPPM) di desa Lencoh ini, prinsip ta'awun menjadi landasan utama pembangunan ekonomi kreatif warga melalui kegiatan produksi wortik (wortel sistik) dengan sebuah alasan penting berupa anjuran Islam (Al-Maidah: 2) dan sebuah pandangan mendasar bahwa seorang mukmin dengan mukmin lainnya seperti pilar bangunan yang saling menopang dan menguatkan sehingga berdirilah (terciptalah) bangunan (sistem ekonomi) yang kokoh, baik dalam masyarakat kecil maupun masyarakat yang besar (majemuk). Ta'awun menganut prinsip tolong-menolong tanpa melihat kawan atau lawan. Hal ini sejalan dengan ungkapan Dr. H. Haedar Nashir, M.Si. (2018) ketua umum Pimpinan Pusat Muhammadiyah dalam pidatonya (Milad 106 Muhammadiyah) yang berjudul 'Ta'awun Untuk Negeri' bahwa spirit ta'awun dalam Islam paralel dengan ajaran ihsan, yang mengandung makna bahwa karena dekatnya seorang muslim dengan Allah Yang Maha Rahman dan Rahim maka dirinya menjadi sosok yang shaleh dan welas asih secara melintasi untuk berbuat segala kebaikan kepada siapapun tanpa pandang bulu.

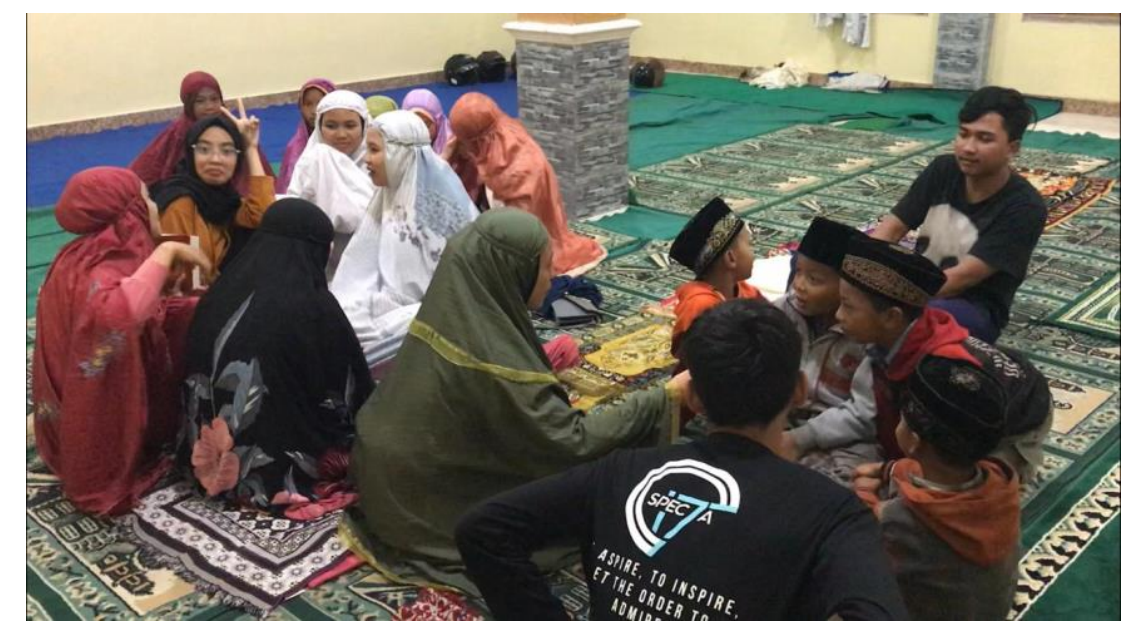

Gambar 4. Pelaksanaan program keIslaman

Sehubungan dengan pemberian motivasi dan spirit ta'awun yang diberikan kepada peserta (ibu-ibu) dalam kegiatan pelatihan tersebut menunjukkan respon yang sangat positif sebagaimana ditunjukkan dengan etos kerja yang tercermin dalam antusias mereka dalam 
mengolah wortel menjadi sistik dan dan kebersamaan yang terjalin dalam kegiatan perlombaan (permainan) yang diberikan.

Dalam tahapan sosialisasi pembuatan wortel sistik, yaitu pada pertemuan pertama di rumah bapak Kadus dusun Wates, bapak Suwarno, disosoalisasikan tatacara pembuatan sistik dengan tahapan-tahapan yang benar serta disampaikan bahan-bahan yang digunakan. Dalam hal ini, ibuibu mendengarkan dan menyimak dengan baik paparan yang diberikan oleh tim pengabdi hingga pada pertemuan berikutnya dilakukan praktik langsung dan ibu-ibu mengikuti arahan yang ditunjukkan. Dalam tahapan ini, para ibu-ibu dibagi menjadi kelompok-kelompok kecil. Sebanyak 26 orang yang datang dalam kegiatan ini, mereka dibagi menjadi 4 kelompok. Tiap kelompok telah diberikan bahan-bahan dan peralatan untuk membuat wortel sistik ini.

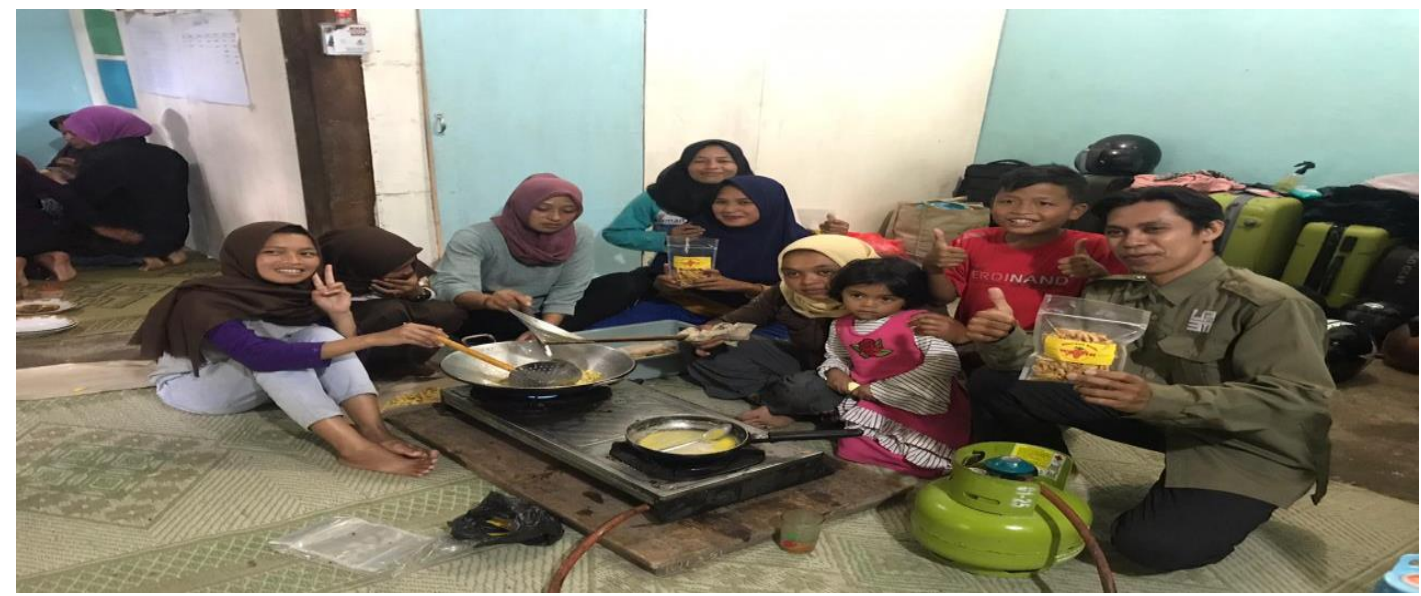

Gambar 5. Pelaksanaan program keahlian keluarga

Sebagaimana telah diajarkan sebelumnya kepada ibu-ibu tentang tatacara pembuatannya, maka pada pertemuan kedua ini para peserta di setiap kelompok sudah hafal dan tahu bagaimana cara pengolahannya. Namun tetap saja ada kendala saat proses pembuatannya, namun hal itu dapat diatasi dengan baik. Pada praktek ini, sistik yang terbuat dari bahan utama wortel telah siap dikonsumsi langsung setelah melewati proses digoreng, dan selanjutnya diajarkan proses pengemasan (packaging) dengan menggunakan plastik khusus (plastik klip) yang sudah disiapkan sekaligus stiker yang sudah didesain sebagai penanda bahwa sistik wortel ini merupakan produksi asli ibu-ibu pedukuhan Wates, desa Lencoh.

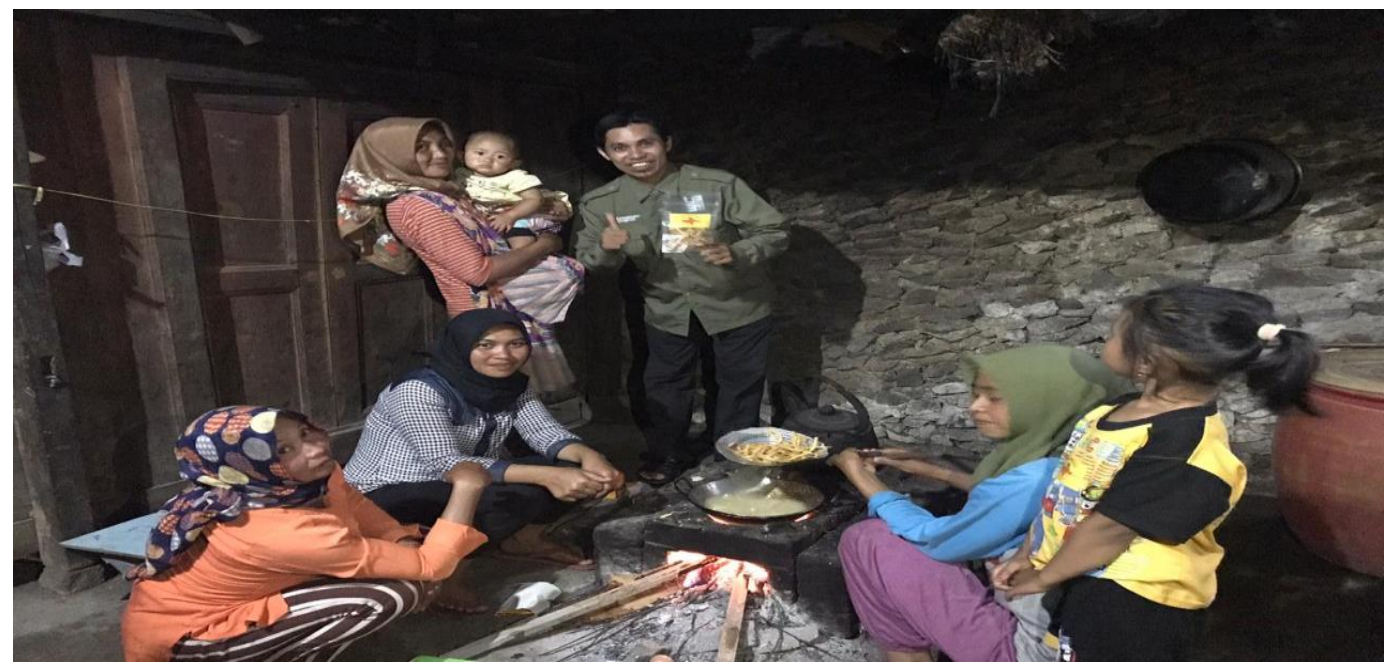

Gambar 6. Pelaksanaan program keahlian keluarga

Bagian pemasaran secara online dilakukan dengan bekerjasama dengan anggota karang taruna di dusun Wates, mengingat anggota karang taruna merupakan usia yang aktif, produktif, kreatif, mudah beradaptasi, mudah bergaul, dan antusias dengan hal-hal yang 
berkaitan dengan media sosial. Selain dipasarkan secara online, sistik wortel ini juga dipasarkan secara offline yaitu dengan cara menitipkan di warung-warung, mini market, dan toko oleh-oleh yang berada di Boyolali terutama daerah yang dekat dengan tempat wisata.

Adapun luaran dari kegiatan ini adalah terhasilnya sebuah produk makanan ringan yang rangup dan enak yang diberi nama oleh tim pengabdian yaitu Wortik (Wortel Sistik) yang harga pemasarannya pun terjangkau. Luaran lainnya berupa artikel ilmiah kegitan KKN-PPM yang diikutkan dalam seminar ABDIMAS ke-3 UMY November 2020. Sebagiamana produk Wortik ini dapat ditunjukkan secara jelas dalam gambar berikut:
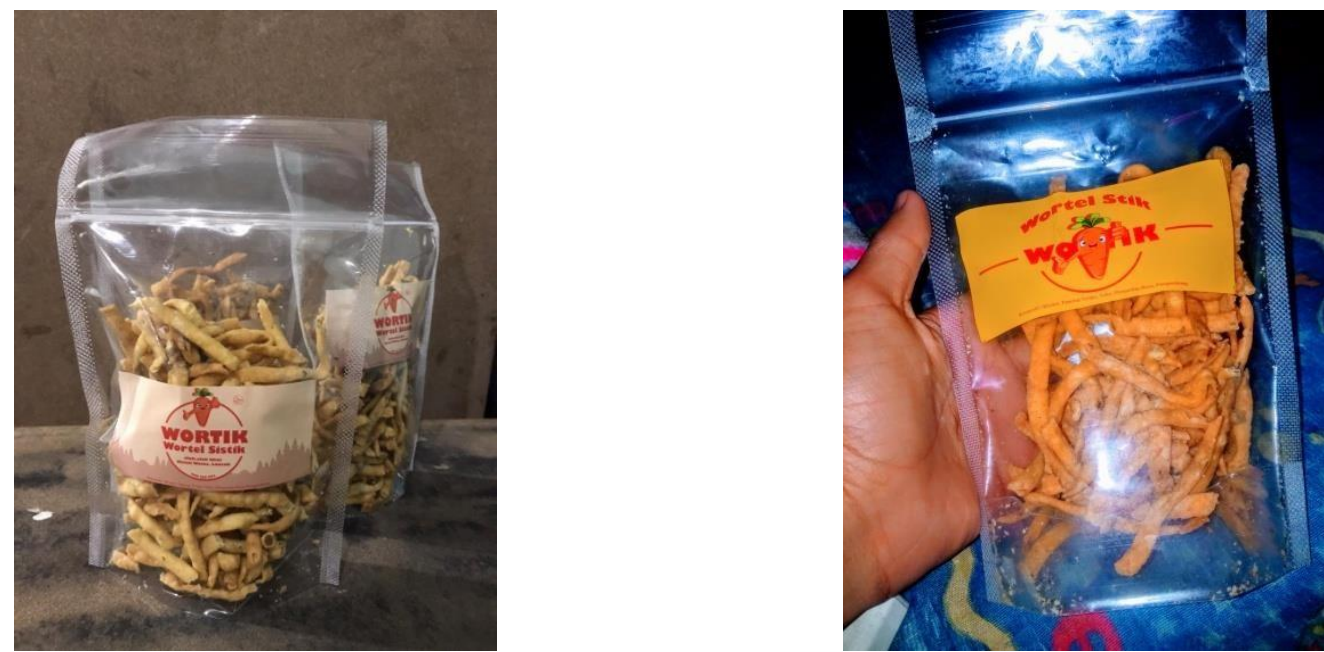

Gambar 7. Contoh hasil pelaksanaan program keahlian keluarga

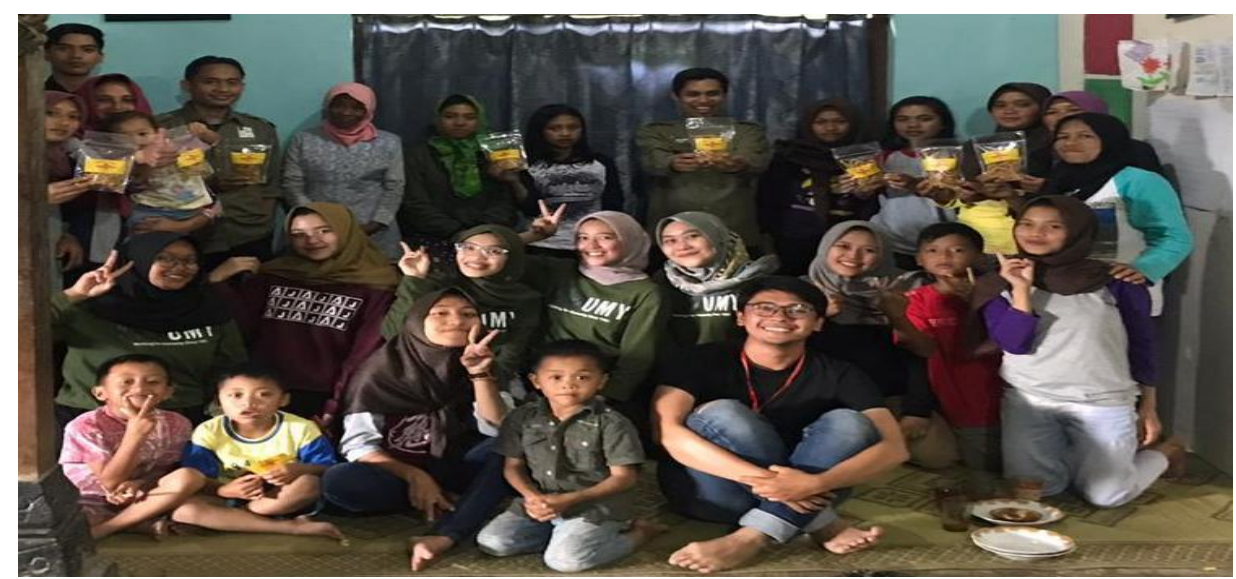

Gambar 8. Tim Pengabdian bersama anggota binaan

\section{Simpulan}

Berdasarkan data yang telah diperoleh dan dianalisis, maka di sini dapat disimpulkan bahwa pemberdayaan ibu-ibu dusun Wates dalam membuat wortel sistik berjalan dengan lancar dan membuahkan hasil yaitu adanya kemampuan dan wawasan baru bagi ibu-ibu dusun Wates dalam menyulap wortel menjadi makanan ringan yang rangup dan enak. Etos kerja peserta pun semakin meningkat yang dibuktikan dengan antusiasnya dan fast response oleh peserta dengan pengolahan wortel secara mandiri dan terbimbing di rumah masing-masing. Nilai dan prinsip ta'awun benar-benar tercermin dalam perilaku warga desa, khususnya ibu-ibu dusun Wates yang bekerja sama membuat makanan ringan Wortel Sistik (Wortik) dan juga bantuan karang taruna dalam memasarkan produk wortik tersebut. 


\section{Ucapan Terima Kasih}

Ribuan terima kasih disampaikan oleh ketua tim pengabdi kepada pihak pemberi dana, LP3M Universitas Muhammadiyah Yogyakarta pada skema program KKN-PPM. Ucapan terima kasih ini juga disampaikan kepada pihak mitra bapak Kadus dusun Wates, Lencoh, Boyolali, serta kepada tim anggota pengabdian, yang telah membantu terlaksananya kegiatan pengabdian ini.

\section{Daftar Pustaka}

Al- Quran Al- Karim.

Long, A. S. (2008). Pengenalan Metodologi Penyelidikan Pengajian Islam. Universiti Kebangsaan Malaysia.

Mubarok, M. F. (2019). PRINSIP TA'AWUN DALAM AL-QUR'AN: STUDI TAFSIR AL-

$S Y A$ 'RAWI. UIN Sunan Gunung Djati Bandung.

Nashir, H. (2018). Ta'awun Untuk Negeri.

Purwanto. (2019). GAMBAR KARYA ANAK-ANAK PEGUNUNGAN : Studi Kasus di SDN

2 Lencoh, Kecamatan Selo, Kabupaten Boyolali. Imajinasi, XIII(2), 27-34.

https://doi.org/https://doi.org/10.15294/imajinasi.v13i2.21932

Suparlan, P. (1980). Manusia, Kebudayaan, dan Lingkungannya: Perspektif Antropologi

Budaya. Makalah Seminar Manusia Dalam Keserasian Lingkungan PSLUI.

http://www.muhammadiyah.or.id/id/download--1263.html

http://desalencoh.blogspot.com/2015/03/visi-dan-misi-desa-lencoh.html 